\title{
Pedobacter daechungensis sp. nov., from freshwater lake sediment in South Korea
}

Correspondence

Chun-Hwi Cho

kafco1002@hanmail.net
Dong-Shan An, ${ }^{1,2}$ Song-Gun Kim, ${ }^{2}$ Leonid N. Ten ${ }^{3}$ and Chun-Hwi Cho ${ }^{4,5}$

${ }^{1}$ Department of Biological Sciences, Korea Advanced Institute of Science and Technology, 373-1 Guseong-dong, Yuseong-gu, Daejeon 305-701, Republic of Korea

${ }^{2}$ Biological Resource Center, KRIBB, Daejeon 305-806, Republic of Korea

${ }^{3}$ Department of Biology and Medicinal Science, Pai Chai University, 14 Yeonja-1-Gil, Seo-Gu, Daejeon 302-735, Republic of Korea

${ }^{4}$ Korea Agriculture Fertilizer Corporation Biochemistry Research Institute, ChungBuk 373-831, Republic of Korea

${ }^{5}$ Department of Bio-Environmental Chemistry, Chungnam National University, Daejeon 305-764, Republic of Korea

A novel bacterial strain, designated Dae $13^{\top}$, was isolated from sediment from a freshwater lake in Daejeon, South Korea, and was characterized taxonomically by using a polyphasic approach. The isolate was Gram-negative, aerobic, non-motile, non-spore-forming and rod-shaped.

Phylogenetic analysis based on 16S rRNA gene sequences indicated that the isolate belonged to the genus Pedobacter in the family Sphingobacteriaceae but was clearly separate from established species of this genus. The 16S rRNA gene sequence similarities between strain Dae $13^{\top}$ and type strains of Pedobacter species with validly published names ranged from 91.6 to $97.5 \%$. The $\mathrm{G}+\mathrm{C}$ content of the genomic DNA was $33.8 \mathrm{~mol} \%$. Chemotaxonomic data, i.e. the presence of MK-7 as the major menaquinone and iso- $\mathrm{C}_{15: 0}, \mathrm{C}_{16: 0}$ and summed feature 3 (iso- $\mathrm{C}_{15: 0} 2-\mathrm{OH}$ and/or $\mathrm{C}_{16: 1} \omega 7 \mathrm{c}$ ) as the major fatty acids, supported the affiliation of strain Dae $13^{\top}$ to the genus Pedobacter. However, the results of physiological and biochemical tests allowed phenotypic differentiation of the isolate with respect to Pedobacter species with validly published names. Therefore, strain Dae $13^{\top}$ represents a novel species within the genus Pedobacter, for which the name Pedobacter daechungensis sp. nov. is proposed. The type strain is Dae $13^{\top}$ $\left(=\right.$ KCTC $12637^{\top}=$ LMG $\left.23489^{\top}\right)$.

The genus Pedobacter was proposed by Steyn et al. (1998) to accommodate species characterized as obligately aerobic, heparinase-producing, Gram-negative rods with or without gliding motility, negative for urease, lipase, gelatinase, arginine dihydrolase, indole production and nitrate reduction and containing fatty acids iso- $\mathrm{C}_{15: 0}$, iso- $\mathrm{C}_{15: 0}$ 2-OH, iso- $\mathrm{C}_{15: 0} 3-\mathrm{OH}, \mathrm{C}_{16: 0}, \mathrm{C}_{16: 1} \omega 5 c, \mathrm{C}_{16: 1} \omega 7 c, \mathrm{C}_{16: 0} 3-$ $\mathrm{OH}$, iso- $\mathrm{C}_{17: 0} 3-\mathrm{OH}$ and iso- $\mathrm{C}_{17: 1} \omega 9 c$. At the time of writing, the genus comprised 16 recognized species, including the recently described species Pedobacter lentus and Pedobacter terricola (Yoon et al., 2007a). In this study, a Pedobacter-like strain, designated Dae $13^{\mathrm{T}}$, was isolated and characterized taxonomically.

Strain Dae $13^{\mathrm{T}}$ was isolated from sediment from the Daechung freshwater lake near Daejeon in South Korea, using direct plating onto R2A agar (Difco). Single colonies on these plates were purified by transferring them onto

The GenBank/EMBL/DDBJ accession number for the 16S rRNA gene sequence of strain Dae $13^{\top}$ is AB267722. new plates and subjecting them to an additional incubation for 3 days at $30{ }^{\circ} \mathrm{C}$. Purified colonies were tentatively identified using partial 16S rRNA gene sequences. Strain Dae $13^{\mathrm{T}}$ was routinely cultured on R2A agar at $30{ }^{\circ} \mathrm{C}$ and maintained as a glycerol suspension $\left(20 \%\right.$, w/v) at $-70{ }^{\circ} \mathrm{C}$.

The Gram reaction was performed by using the nonstaining method as described by Buck (1982). Cell morphology was observed at $\times 1000$ magnification with a light microscope (Nikon), using cells grown on R2A agar for 3 days at $30{ }^{\circ} \mathrm{C}$. Motility was tested by using the hanging drop technique. Catalase activity was determined by assessing bubble production in $3 \%(\mathrm{v} / \mathrm{v}) \mathrm{H}_{2} \mathrm{O}_{2}$ and oxidase activity was determined using $1 \%(\mathrm{w} / \mathrm{v})$ tetramethyl- $p$-phenylenediamine. Carbon-source utilization and enzyme activities were tested by using API 20E, API 20NE and API ZYM test kits (bioMérieux). Anaerobic growth was tested in serum bottles by adding sodium thioglycolate $\left(1 \mathrm{~g} \mathrm{l}^{-1}\right)$ to R2A broth (Difco) and substituting the upper air layer with nitrogen gas. Growth at 
different temperatures $\left(4,15,20,25,30,37\right.$ and $\left.42{ }^{\circ} \mathrm{C}\right)$ and various $\mathrm{pH}$ values $(\mathrm{pH} 5.0-10.0$, using increments of 0.5 $\mathrm{pH}$ units) was assessed after 5 days incubation. Salt tolerance was tested after 5 days incubation on R2A agar supplemented with $1-10 \%(\mathrm{w} / \mathrm{v}) \mathrm{NaCl}$. Growth on nutrient agar, trypticase soy agar (Difco) and MacConkey agar (Difco) was also evaluated, at $30{ }^{\circ} \mathrm{C}$.

Cells of strain Dae $13^{\mathrm{T}}$ were strictly aerobic, Gramnegative, non-motile, non-spore-forming and rod-shaped. Colonies grown on R2A agar plates for 4 days were sticky, smooth, circular, reddish orange in colour and $0.5-1 \mathrm{~mm}$ in diameter. The isolate grew well on nutrient agar and trypticase soy agar, but could not grow on MacConkey agar. Other physiological characteristics of strain Dae $13^{\mathrm{T}}$ are summarized in the species description. Phenotypic characteristics that serve to differentiate the isolate from its closest phylogenetic relatives are listed in Table 1.

To measure the $\mathrm{G}+\mathrm{C}$ content of the chromosomal DNA, genomic DNA was extracted from the novel strain and purified as described by Moore \& Dowhan (1995) before being enzymically degraded into nucleosides and determined as described by Mesbah et al. (1989) using reversedphase HPLC. Isoprenoid quinones were extracted with chloroform/methanol $(2: 1, \quad \mathrm{v} / \mathrm{v})$, evaporated under vacuum conditions and re-extracted in $n$-hexane/water $(1: 1, \mathrm{v} / \mathrm{v})$. The crude $n$-hexane-quinone solution was purified using Sep-Pak Vac silica cartridges (Waters) and subsequently analysed using HPLC as described by Hiraishi et al. (1996). Cellular fatty acid profiles were determined for strains grown on trypticase soy agar for 5 days. The cellular fatty acids were saponified, methylated and extracted according to the protocol of the Sherlock Microbial Identification System (MIDI). The fatty acids were analysed using a gas chromatograph (6890; Hewlett Packard) and identified with the Microbial Identification software package (Sasser, 1990).

The G $+C$ content of genomic DNA of strain Dae $13^{\mathrm{T}}$ was $33.8 \mathrm{~mol} \%$. The predominant menaquinone was MK-7. The fatty acid profile of strain Dae $13^{\mathrm{T}}$ comprised branchedchain fatty acids iso- $\mathrm{C}_{15: 0}(22.4 \%)$, iso- $\mathrm{C}_{17: 0} 3-\mathrm{OH}(1.5 \%)$, iso- $\mathrm{C}_{17: 1} \omega 9 c(3.4 \%)$, iso- $\mathrm{C}_{15: 0} 3-\mathrm{OH}(2.1 \%)$ and iso- $\mathrm{C}_{17: 0}$ $(0.9 \%)$, unsaturated fatty acid $\mathrm{C}_{16: 1} \omega 5 c(0.6 \%)$, saturated fatty acids $\mathrm{C}_{16: 0}(10.7 \%)$ and $\mathrm{C}_{15: 0}(1.2 \%)$, hydroxyl fatty acid $\mathrm{C}_{16: 0} 3-\mathrm{OH}(2.6 \%)$ and summed feature 3 (iso- $\mathrm{C}_{15: 0}$ 2-OH and/or $\left.\mathrm{C}_{16: 1} \omega 7 c\right)(48.1 \%)$. This fatty acid profile, including the major fatty acids [iso- $\mathrm{C}_{15: 0}, \mathrm{C}_{16: 0}$ and summed feature 3 (iso- $\mathrm{C}_{15: 0} 2-\mathrm{OH}$ and/or $\mathrm{C}_{16: 1} \omega 7 c$ )], is

Table 1. Comparison of phenotypic characteristics of strain Dae $13^{\top}$ and related species of the genus Pedobacter

Taxa: 1, strain Dae $13^{\mathrm{T}}$ (Pedobacter daechungensis sp. nov.); 2, P. lentus DS-40 ${ }^{\mathrm{T}}$; 3, P. terricola DS-45 ${ }^{\mathrm{T}}$; 4, Pedobacter heparinus. Data for taxa 2-4 are from Yoon et al. (2007a). All strains were positive for catalase, oxidase, alkaline phosphatase, esterase (C4), esterase lipase (C8), leucine arylamidase, valine arylamidase, cystine arylamidase, hydrolysis of aesculin and assimilation of L-arabinose, D-glucose, D-mannose, L-rhamnose, maltose and $N$ acetylglucosamine. All were negative for Gram stain, sporulation, urease, lipase (C14), trypsin, $\beta$-glucuronidase, $\alpha$-fucosidase, production of $\mathrm{H}_{2} \mathrm{~S}$ and indole, nitrate reduction, growth on MacConkey medium and assimilation of D-arabinose, D-fucose, L-arabitol, adipate, caprate, phenylacetate, ribose, D-sorbitol, salicin, melibiose, citrate and malate.

\begin{tabular}{|c|c|c|c|c|}
\hline Characteristic & 1 & 2 & 3 & 4 \\
\hline Cell shape & Short rods & Pleomorphic & Pleomorphic & Short rods \\
\hline Colony colour & Reddish orange & $\begin{array}{c}\text { Pale yellow to pale } \\
\text { orange }\end{array}$ & $\begin{array}{c}\text { Pale yellow to pale } \\
\text { orange }\end{array}$ & Translucent yellow \\
\hline Maximum growth temperature $\left({ }^{\circ} \mathrm{C}\right)$ & 30 & 31 & 34 & 37 \\
\hline Motility & - & - & - & Gliding \\
\hline Arginine dihydrolase & + & - & - & - \\
\hline \multicolumn{5}{|l|}{ Assimilation of: } \\
\hline Gluconate & + & - & - & - \\
\hline Inositol & + & - & - & - \\
\hline Mannitol & + & - & - & + \\
\hline Sucrose & + & - & - & - \\
\hline \multicolumn{5}{|l|}{ API ZYM tests } \\
\hline Acid phosphatase & - & + & + & + \\
\hline$\alpha$-Chymotrypsin & - & + & + & + \\
\hline Naphthol-AS-BI-phosphohydrolase & - & + & + & + \\
\hline$\alpha$-Galactosidase & - & - & - & + \\
\hline$\beta$-Galactosidase & - & + & + & + \\
\hline$\alpha$-Glucosidase & - & + & + & + \\
\hline$\beta$-Glucosidase & + & - & - & + \\
\hline$N$-Acetyl- $\beta$-glucosaminidase & - & + & + & + \\
\hline$\alpha$-Mannosidase & - & - & - & + \\
\hline DNA G $+C$ content $(\mathrm{mol} \%)$ & 33.8 & 36.0 & 36.8 & $42.3-43.0$ \\
\hline
\end{tabular}


similar to those of Pedobacter species, although there are differences in the proportions of some fatty acids, perhaps because of differences in the extraction and cultivation conditions (Shivaji et al., 2005; Vanparys et al., 2005; Yoon et al., 2006, 2007a, b; Hwang et al., 2006; Ten et al., 2006).

Extraction of genomic DNA, PCR-mediated amplification of the $16 \mathrm{~S}$ rRNA gene and sequencing of the purified PCR product were carried out as described by Kim et al. (2005). Full sequences of the $16 \mathrm{~S}$ rRNA gene were compiled using SeqMan software (DNASTAR). The 16S rRNA gene sequences of related taxa were obtained from GenBank. Multiple alignments were performed with the CLUSTAL_X program (Thompson et al., 1997) and gaps were edited in the BioEdit program (Hall, 1999). Evolutionary distances were calculated using the Kimura two-parameter model (Kimura, 1983). Phylogenetic trees were constructed with the neighbour-joining method (Saitou \& Nei, 1987), using the MEGA3 program (Kumar et al., 2004) and bootstrap values based on 1000 replications (Felsenstein, 1985). DNA-DNA hybridization was performed fluorometrically according to the method of Ezaki et al. (1989), using photobiotin-labelled DNA probes and microdilution wells. Hybridization was performed using five replications for each sample. The highest and lowest values obtained for each sample were excluded and the remaining three values were used to calculate similarity values. The DNA hybridization values quoted are the means of these three values.
An almost-complete 16S rRNA gene sequence (1467 bp) for Dae $13^{\mathrm{T}}$ was determined and subjected to phylogenetic analysis, which indicated that the strain belongs to the genus Pedobacter (Fig. 1). Strain Dae $13^{\mathrm{T}}$ showed the highest $16 \mathrm{~S}$ rRNA gene sequence similarity with respect to P. lentus DS $-40^{\mathrm{T}}(97.5 \%)$ and showed $33 \%$ DNA-DNA hybridization; this was followed by $P$. terricola DS- $45^{\mathrm{T}}$ $(95.9 \%)$ and other species in the genus Pedobacter $(<94 \%)$. These values $(<97 \%)$ and the DNA-DNA hybridization values were sufficiently low to classify strain Dae $13^{\mathrm{T}}$ as representing a novel species within the genus Pedobacter (according to Stackebrandt \& Goebel, 1994).

On the basis of the data described above, strain Dae $13^{\mathrm{T}}$ should be assigned to the genus Pedobacter as the type strain of a novel species, for which the name Pedobacter daechungensis sp. nov. is proposed.

\section{Description of Pedobacter daechungensis sp. nov.}

Pedobacter daechungensis (dae.chun.gen'sis. N.L. masc. adj. daechungensis pertaining to Daechung lake).

Cells are Gram-negative, strictly aerobic, non-motile and $0.3-0.4 \mu \mathrm{m}$ wide and $0.8-1.3 \mu \mathrm{m}$ long after 4 days culture on R2A agar. Colonies grown on R2A agar for 4 days are sticky, smooth, circular, convex and reddish orange in colour. Good growth occurs at $30{ }^{\circ} \mathrm{C}$ and at $\mathrm{pH}$ 7.0.

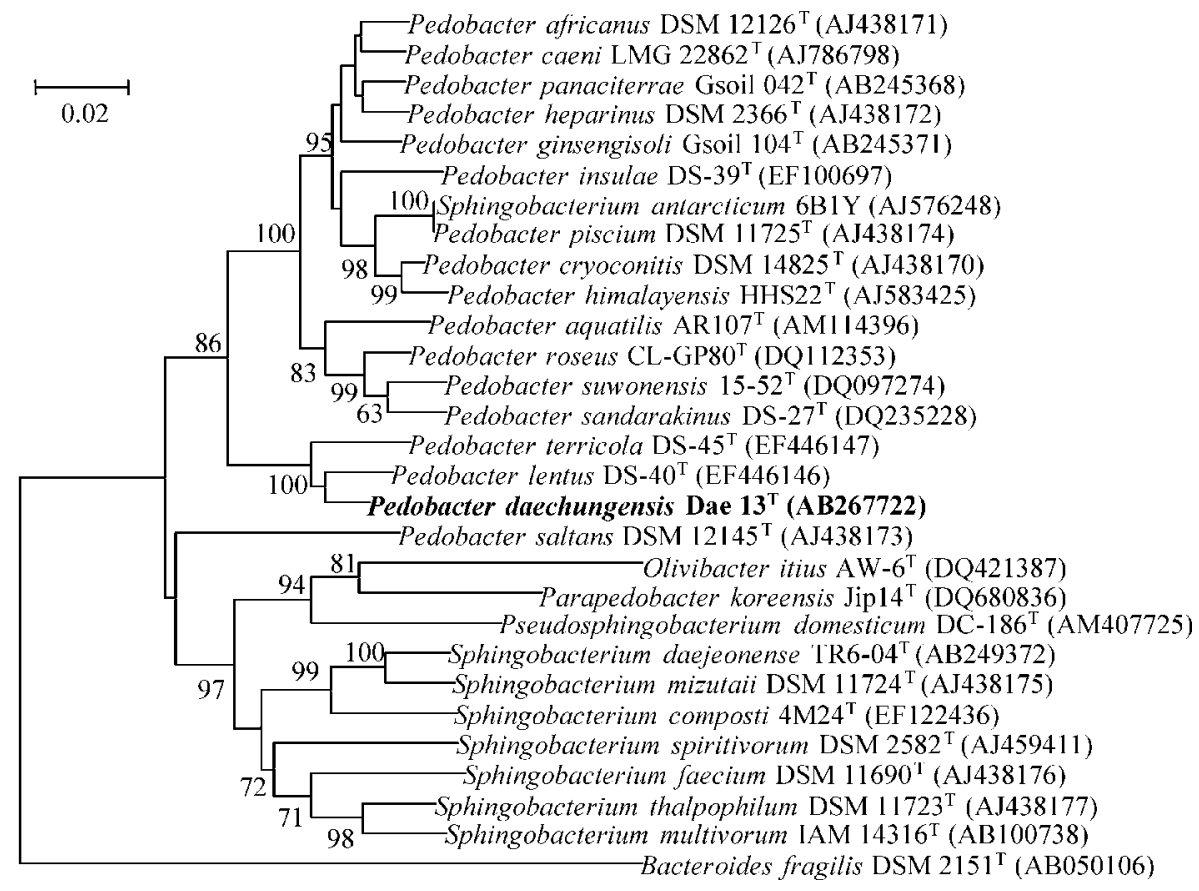

Fig. 1. Phylogenetic tree, based on $16 \mathrm{~S}$ rRNA gene sequences, showing the relationships between strain Dae $13^{\top}$ and related species. The tree was constructed using the neighbour-joining method (Saitou \& Nei, 1987) with a Kimura two-parameter distance matrix (Kimura, 1983) and pairwise deletion. Bootstrap values (expressed as percentages of 1000 replications) greater than $60 \%$ are shown at branch points. Bar, 0.02 substitutions per nucleotide position. 
Growth is observed at $15-30{ }^{\circ} \mathrm{C}$, at $\mathrm{pH} 5.0-8.0$ and with 0 $1 \%(\mathrm{w} / \mathrm{v}) \mathrm{NaCl}$. Nitrate is not reduced. Anaerobic growth does not occur. The substrates utilized, the enzymes produced and other physiological characteristics are indicated in Table 1. In addition, citrate, L-lactate, mannitol and $\mathrm{L}$-serine are utilized as sole carbon sources. The following are not utilized as sole carbon sources: acetate, L-alanine, glycogen, L-histidine, 3-hydroxybenxoate, 4-hydroxybenzoate, 3-hydroxybutyrate, itaconate, 2-ketogluconate, malonate, propionate, L-proline, suberate and valerate. The predominant menaquinone is MK-7. The major fatty acids are iso- $\mathrm{C}_{15: 0}, \mathrm{C}_{16: 0}$ and summed feature 3 (iso- $\mathrm{C}_{15: 0} 2-\mathrm{OH}$ and/or $\left.\mathrm{C}_{16: 1} \omega 7 \mathrm{c}\right)$. The $\mathrm{G}+\mathrm{C}$ content of the genomic DNA of the type strain is $33.8 \mathrm{~mol} \%$. Other phenotypic characteristics are given in Table 1 .

The type strain, Dae $13^{\mathrm{T}}\left(=\right.$ KCTC $\left.12637^{\mathrm{T}}=\mathrm{LMG} 23489^{\mathrm{T}}\right)$, was isolated from sediment collected from a freshwater lake in Daejeon, South Korea.

\section{Acknowledgements}

We thank Jean Euzéby for his help with the etymology of the species epithet. This study was supported by a grant from the KRIBB Research Initiative Program.

\section{References}

Buck, J. D. (1982). Nonstaining (KOH) method for determination of Gram reactions of marine bacteria. Appl Environ Microbiol 44, 992-993.

Ezaki, T., Hashimoto, Y. \& Yabuuchi, E. (1989). Fluorometric deoxyribonucleic acid-deoxyribonucleic acid hybridization in microdilution wells as an alternative to membrane filter hybridization in which radioisotopes are used to determine genetic relatedness among bacterial strains. Int J Syst Bacteriol 39, 224-229.

Felsenstein, J. (1985). Confidence limits on phylogenies: an approach using the bootstrap. Evolution 39, 783-791.

Hall, T. A. (1999). BioEdit: a user-friendly biological sequence alignment editor and analysis program for Windows 95/98/NT. Nucleic Acids Symp Ser 41, 95-98.

Hiraishi, A., Ueda, Y., Ishihara, J. \& Mori, T. (1996). Comparative lipoquinone analysis of influent sewage and activated sludge by highperformance liquid chromatography and photodiode array detection. J Gen Appl Microbiol 42, 457-469.

Hwang, C. Y., Choi, D. H. \& Cho, B. C. (2006). Pedobacter roseus sp. nov., isolated from a hypertrophic pond, and emended description of the genus Pedobacter. Int J Syst Evol Microbiol 56, 1831-1836.

Kim, M. K., Im, W.-T., Ohta, H., Lee, M. \& Lee, S.-T. (2005). Sphingopyxis granuli sp. nov., a $\beta$-glucosidase producing bacterium in the family Sphingomonadaceae in $\alpha-4$ subclass of the Proteobacteria. J Microbiol 43, 152-157.

Kimura, M. (1983). The Neutral Theory of Molecular Evolution. Cambridge: Cambridge University Press.
Kumar, S., Tamura, K. \& Nei, M. (2004). MEGA3: Integrated Software for Molecular Evolutionary Genetics Analysis and sequence alignment. Brief Bioinform 5, 150-163.

Mesbah, M., Premachandran, U. \& Whitman, W. B. (1989). Precise measurement of the $\mathrm{G}+\mathrm{C}$ content of deoxyribonucleic acid by highperformance liquid chromatography. Int J Syst Bacteriol 39, 159-167.

Moore, D. D. \& Dowhan, D. (1995). Preparation and analysis of DNA. In Current Protocols in Molecular Biology, pp. 2-11. Edited by F. W. Ausubel, R. Brent, R. E. Kingston, D. D. Moore, J. G. Seidman, J. A. Smith \& K. Struhl. New York: Wiley.

Saitou, N. \& Nei, M. (1987). The neighbor-joining method: a new method for reconstructing phylogenetic trees. Mol Biol Evol 4, 406425.

Sasser, M. (1990). Identification of bacteria by gas chromatography of cellular fatty acids, MIDI Technical Note 101. Newark, DE: MIDI Inc.

Shivaji, S., Chaturvedi, P., Reddy, G. S. N. \& Suresh, K. (2005). Pedobacter himalayensis sp. nov., from the Hamta glacier located in the Himalayan mountain ranges of India. Int J Syst Evol Microbiol 55, 1083-1088.

Stackebrandt, E. \& Goebel, B. M. (1994). Taxonomic note: a place for DNA-DNA reassociation and 16S rRNA sequence analysis in the present species definition in bacteriology. Int J Syst Bacteriol 44, 846849.

Steyn, P. L., Segers, P., Vancanneyt, M., Sandra, P., Kersters, K. \& Joubert, J. J. (1998). Classification of heparinolytic bacteria into a new genus, Pedobacter, comprising four species: Pedobacter heparinus comb. nov., Pedobacter piscium comb. nov., Pedobacter africanus sp. nov. and Pedobacter saltans sp. nov. Proposal of the family Sphingobacteriaceae fam. nov. Int J Syst Bacteriol 48, 165-177.

Ten, L. N., Im, W.-T., Kim, M.-K., Kang, M.-S. \& Lee, S.-T. (2004). Development of a plate technique for screening of polysaccharidedegrading microorganisms by using a mixture of insoluble chromogenic substrates. J Microbiol Methods 56, 375-382.

Ten, L. N., Liu, Q.-M., Im, W.-T., Lee, M., Yang, D.-C. \& Lee, S.-T. (2006). Pedobacter gingsengisoli sp. nov., a DNase-producing bacterium isolated from soil of a ginseng field in South Korea. Int J Syst Evol Microbiol 56, 2565-2570.

Thompson, J. D., Gibson, T. J., Plewniak, F., Jeanmougin, F. \& Higgins, D. G. (1997). The CLUSTAL_X windows interface: flexible strategies for multiple sequence alignment aided by quality analysis tools. Nucleic Acids Res 25, 4876-4882.

Vanparys, B., Heylen, K., Lebbe, L. \& De Vos, P. (2005). Pedobacter caeni sp. nov., a novel species isolated from a nitrifying inoculum. Int J Syst Evol Microbiol 55, 1315-1318.

Yoon, J.-H., Lee, M.-H., Kang, S.-J., Park, S.-Y. \& Oh, T.-K. (2006). Pedobacter sandarakinus sp. nov., isolated from soil. Int J Syst Evol Microbiol 56, 1273-1277.

Yoon, J.-H., Kang, S.-J., Park, S. \& Oh, T.-K. (2007a). Pedobacter lentus sp. nov. and Pedobacter terricola sp. nov., isolated from soil. Int J Syst Evol Microbiol 57, 2089-2095.

Yoon, M.-H., Ten, L. N., Im, W.-T. \& Lee, S.-T. (2007b). Pedobacter panaciterrae sp. nov., isolated from soil in South Korea. Int J Syst Evol Microbiol 57, 381-386. 